\title{
Paleomagnetism of the Eastern Alkaline Province (Mexico): contribution to the time-averaged field global database and geomagnetic instability time scale
}

\author{
Avto Goguitchaichvili ${ }^{1,2 *}$, Marie Petronille ${ }^{3}$, Bernard Henry ${ }^{3}$, Luis Alva Valdivia ${ }^{1}$, Juan Morales ${ }^{1}$, and Jaime Urrutia-Fucugauchi ${ }^{1}$ \\ ${ }^{1}$ Laboratorio de Paleomagnetismo y Geofísica Nuclear, Instituto de Geofísica, Universidad Nacional Autónoma de México, \\ Ciudad Universitaria S/N, 04510 México, DF, Mexico \\ ${ }^{2}$ Laboratorio Interinstitucional de Magnetismo Natural, Instituto de Geofisica, sede Michoacán, Universidad \\ Nacional Autónoma de México, Mexico \\ ${ }^{3}$ Paléomagnétisme, IPGP and CNRS, 4, Av. de Neptune, 94107 Saint Maur cedex, France
}

(Received November 23, 2006; Revised February 1, 2007; Accepted February 16, 2007; Online published July 20, 2007)

\begin{abstract}
We report a detailed paleomagnetic and rock-magnetic study of 19 independent lava flows belonging to the Eastern Alkaline Province (EAP) in Mexico. In total, 162 oriented samples were collected in four areas (Sierra de Tantima-Alamo, Tlanchinol, Chiconquiaco-Palma Sola and Poza Rica). All sites analyzed in this study were previously dated by means of the unspiked K-Ar geochronological method (Ferrari et al., J. Volcanol. Geotherm. Res., 146, 284-306, 2005) and span from 14.6 to 1.5 Ma. Rock-magnetic experiments point to simple magnetic mineralogy. In most cases, the remanence is carried by Ti-poor titanomagnetite of pseudosingle-domain grain size. In a few cases, Ti-rich titanomagnetites are responsible for the magnetization. The characteristic paleodirections are successfully isolated for all of the studied units. The mean paleodirection, discarding two intermediate polarity sites, is $D=359.5^{\circ}, I=32.9^{\circ}, n=17, k=30, \alpha_{95}=6.7^{\circ}$. This direction is practically undistinguishable from the expected Mio-Pliocene paleodirections, as derived from reference poles for the North American polar wander curve, and is in agreement with the previously reported directions from the western Trans-Mexican Volcanic Belt. This suggests that no major tectonic rotation occurred in studied area since the middle Miocene to Present. The paleosecular variation is estimated through the study of the scatter of virtual geomagnetic poles, giving $S_{F}=12.7$ with $S_{U}=16.5$ and $S_{L}=10.3$ (upper and lower limits, respectively). These values are consistent with those predicted by the latitude-dependent variation model of McFadden et al. (Geophys. Res., 93, 11583-11588, 1991) for the last 5 Myr. Eleven sites yielded reverse magnetic polarity, six are normally magnetized and two lava flows provided apparently intermediate paleodirections. An interesting feature of the paleomagnetic record obtained from EAP volcanics is that two independent lava flows, dated as $2.04 \pm 0.04$ and $1.97 \pm 0.04 \mathrm{Ma}$, respectively, both yield normal paleodirections during the reverse Matuyama period. These sites were apparently formed during the Réunion geomagnetic event worldwide observed.
\end{abstract}

Key words: Paleomagnetism, paleosecular variation, geomagnetic reversal, volcanic province, Mexico.

\section{Introduction}

The Trans-Mexican Volcanic Belt (TMVB), one of the largest continental volcanic arcs on the American continent, is related to Neogene subduction of the Cocos and Rivera plates beneath the southwestern margin of the North American plate. The basal units of the TMVB are of late Miocene age, and in the western sector, they cover the Eocene to early Miocene Sierra Madre Occidental siliceous volcanic province. TMVB is $20-150 \mathrm{~km}$ wide and $1000 \mathrm{~km}$ long. It corresponds to a volcanic plateau approximately 1000$2000 \mathrm{~m}$ high, which roughly extends from the Pacific Ocean to the Gulf of Mexico (Fig. 1).

A NNW-trending belt (about $1500 \mathrm{~km}$ in length) of mafic

*Current address (sabbatical): Departamento de Geologia y Mineralogia, Universidad Michoacana de San Nicolas de Hidalgo, Mexico.

Copyright (c) The Society of Geomagnetism and Earth, Planetary and Space Sciences (SGEPSS); The Seismological Society of Japan; The Volcanological Society of Japan; The Geodetic Society of Japan; The Japanese Society for Planetary Sciences; TERRAPUB. alkaline volcanic fields runs from the U.S. border to the southern part of the Mexican state of Veracruz (Fig. 1), intersecting the subduction-related TMVB in Central Veracruz. Robin (1976) defined this belt as the Eastern Alkaline Province (EAP) and suggested that it represented intraplate volcanism migrating from north to south from the Oligocene to the Present. Based on conventional K-Ar datings carried out in a later study, Robin (1982) showed that the EAP would result from Gulf-parallel extensional faulting and would be unrelated to the subduction of the Cocos plate. Gomez-Tuena et al. (2003), however, provided a detailed petrological study of three volcanic successions of this area and interpreted the isotopic characteristics of the Neogene volcanism as controlled by the variation in the time of the depth of the subducting Cocos slab. A large body of reliable data is now available on the TMVB (e.g. Petronille et al., 2005; Mejia et al., 2005; Rodriguez-Ceja et al., 2006) for the last $3 \mathrm{Myr}$ that can be directly compared with EAP mean paleodirections. However, to date, no specific paleomagnetic investigation has focused on EAP vol- 


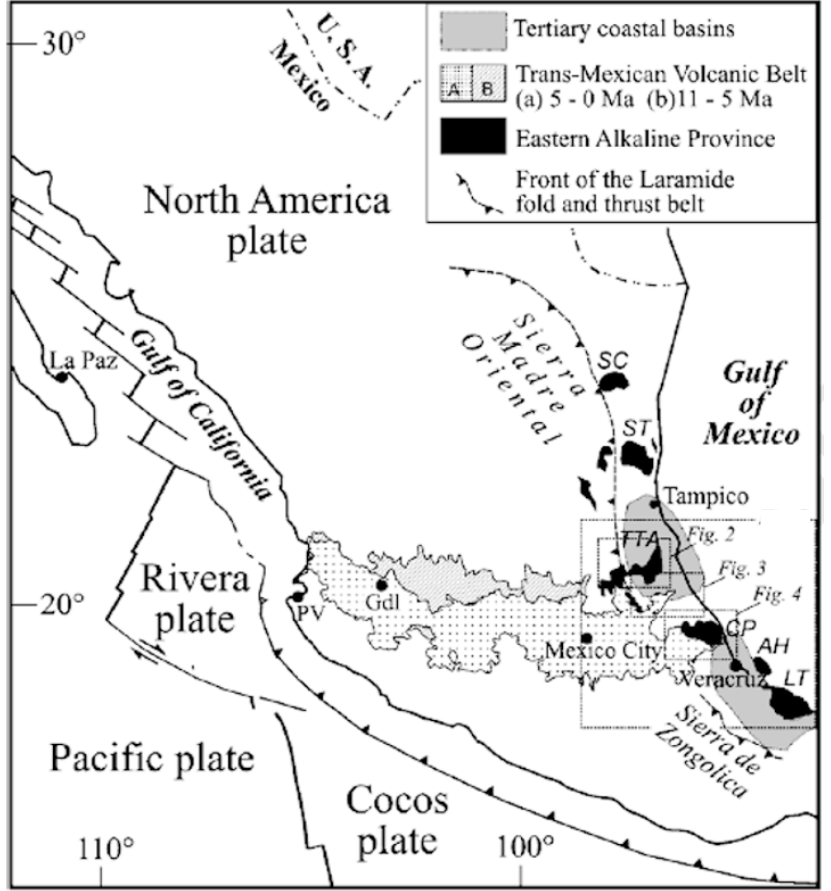

Fig. 1. Schematic geodynamic map of Mexico showing the location of the Eastern Alkaline Province: Sierra de Carlos (SC), Sierra de Tamaulipas (ST), Tlanchinol-Alamo (TTA), Chiconquiaco-Palma Sola (CP), Anegada High (AH), Los Tuxtlas (LT). PV, Puerto Vallarta; Gdl, Guadalajara (retrieved from Ferrari et al., 2005).

canics. Some of the earlier investigations (Bohnel and Negendank, 1981; Ruiz-Martinez et al., 2000) are limited to the Palma Sola massif, which has been considered to be the eastern part of the TMVB.

Paleomagnetic studies of the Plio-Quaternary volcanic sequences have focused on the paleosecular variation (PSV) characteristics for Central Mexico, with contrasting conclusions in terms of the amount of paleosecular variation as estimated by the angular dispersion of virtual geomagnetic poles (VGP). Steele (1985) estimated the VGP dispersion for the latitude of Central Mexico as $14.2^{\circ}$, which is similar to the range predicted for paleosecular variation models assuming that the area was characterized by 'normal' secular variation during the Brunhes chron at the very least. Urrutia-Fucugauchi (1994), however, provides a substantially lower value $\left(7.4^{\circ}\right)$, which is in clear disagreement with the latitude-dependent paleosecular variation models. This author argued that the area may form part of the Central Pacific non-dipole region. A number of other studies also provided contradictory results (e.g., Herrero-Bervera et al., 1986; Bohnel et al., 1990; Urrutia-Fucugauchi, 1997; Gonzalez et al., 1997; Mejia et al., 2005; Petronille et al., 2005). More recently, Lawrence et al. (2006) investigated geomagnetic field behavior during the past $5 \mathrm{Myr}$ and addressed whether geographical differences have been recorded by a selected data set, giving some arguments against earlier ideas of a "Pacific non-dipole window".

The polarity changes and excursions for the last Myr is still a matter of debate (Singer et al., 2002; Coe et al., 2004; Petronille et al., 2005). As early as 1968, Cox predicted that there should be numerous undiscovered geomagnetic
Table 1. Available isotopic age determinations for EAP volcanic lava flows (Ferrari et al., 2005).

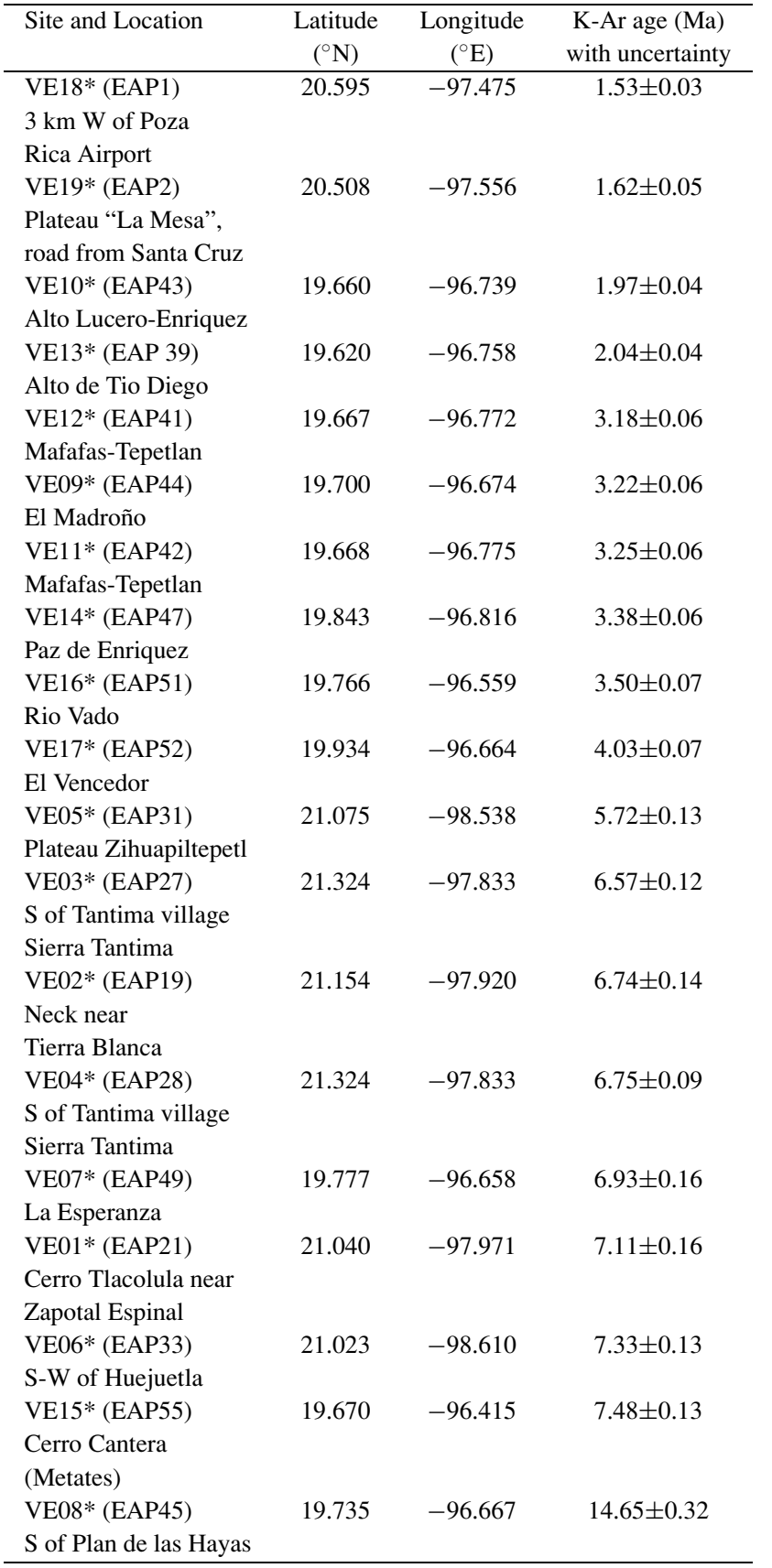

events (excursions or shorter reversed intervals) within the Brunhes chron. The most recent Geomagnetic Instability Time Scale (GITS, proposed by Singer et al., 2002) to describe geochronology of excursions) shows evidence for 14 geomagnetic excursions in the Brunhes. Pre-Brunhes periods are poorly constrained.

Both PSV and GITS studies are limited when the age of the studied units is poorly constrained. In this study, we report a detailed rock-magnetic and paleomagnetic investigation of lava flows of the Eastern Alkaline Province (eastern Mexico). All of these sites were recently radiometrically dated by Ferrari et al. (2005). The aim of our investigation was to contribute to the regional tectonics, time-averaged field and geomagnetic instability time scale. 


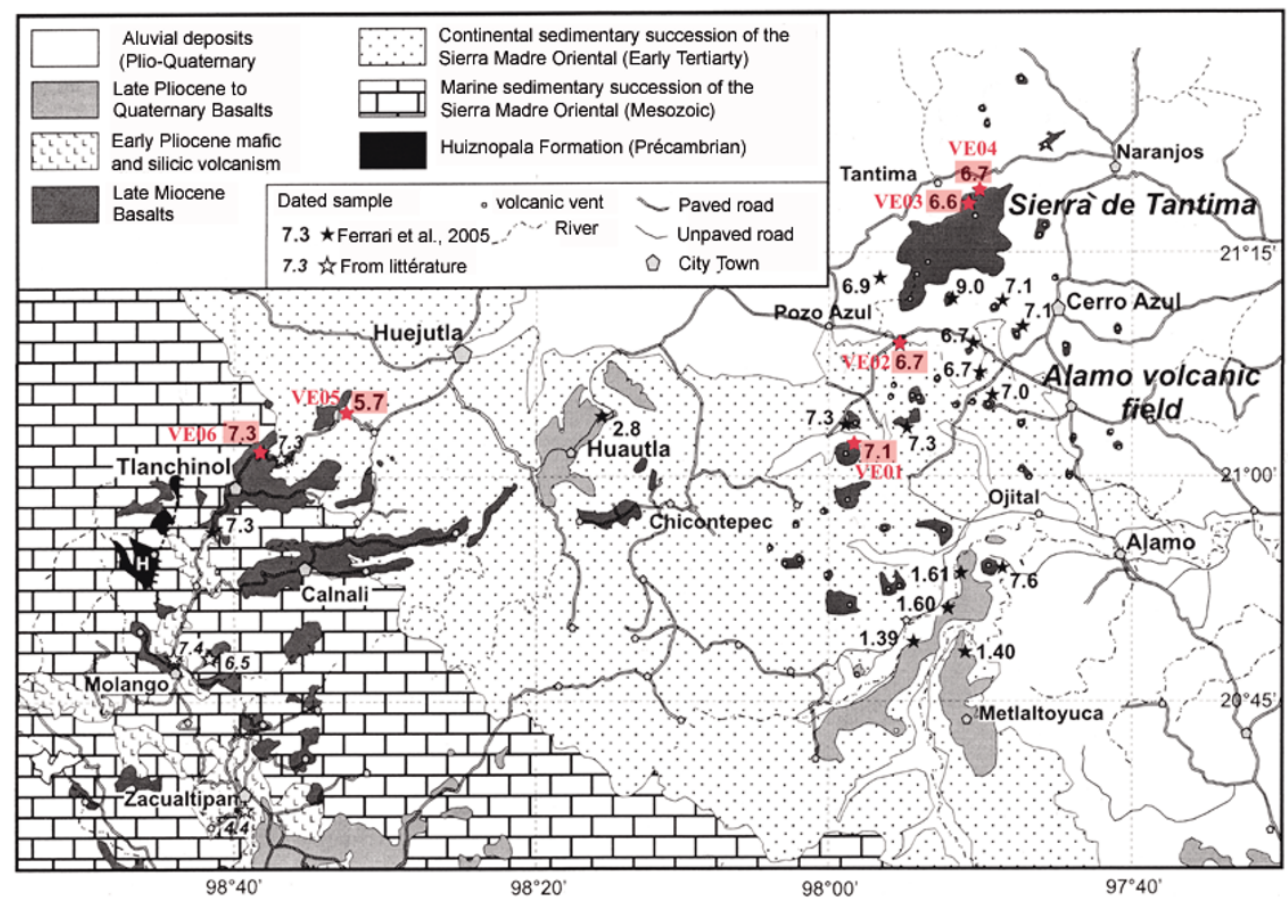

Fig. 2. Geological map of the Tlanchinol-Tantima-Alamo region with locations of sampling sites. Sites V01-VE06, with their respective K-Ar ages (retrieved from Ferrari et al., 2005).

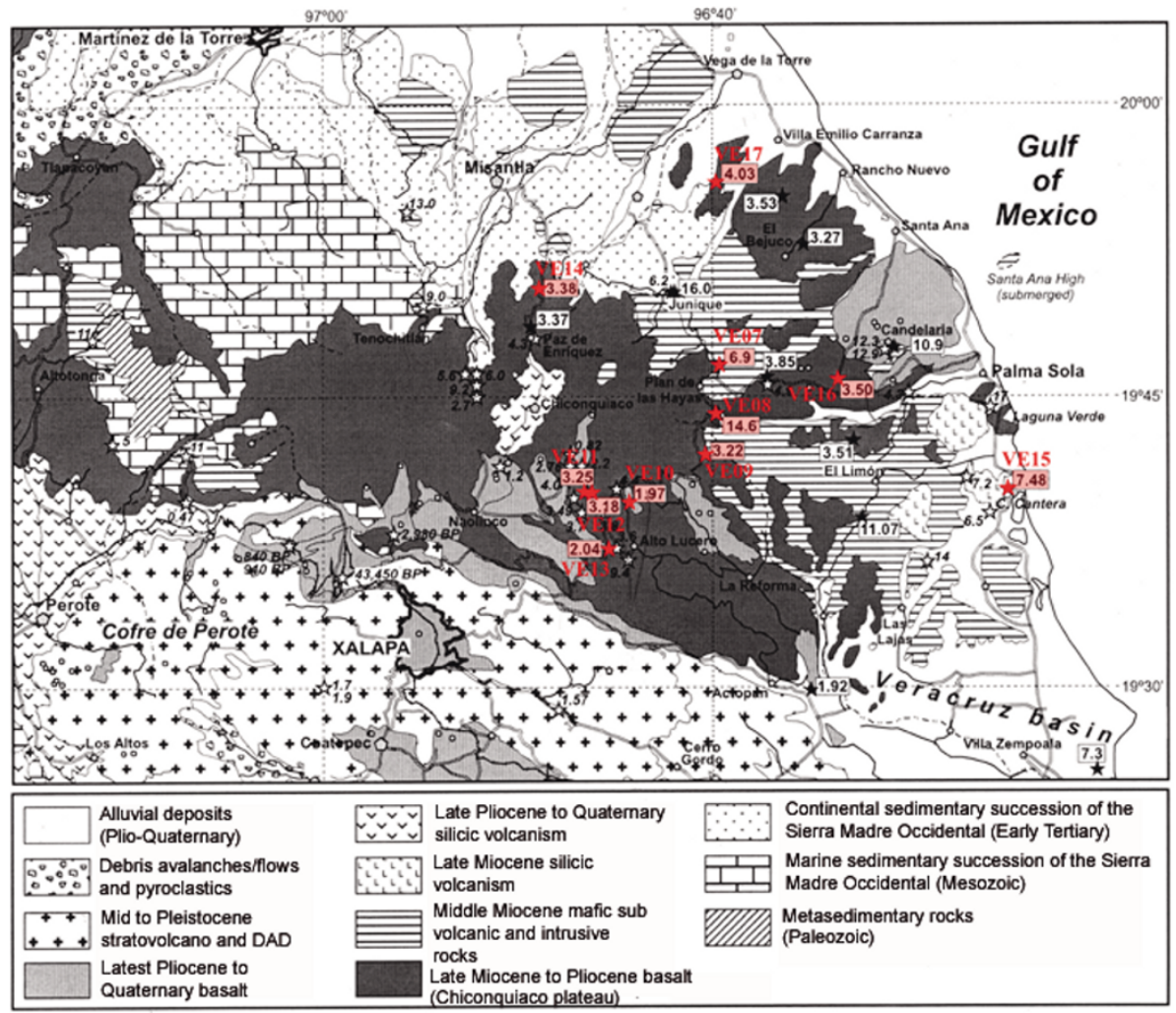

Fig. 3. Geological map of the Chiconquiaco-Palma Sola area. Sites VE07-VE17 (retrieved from Ferrari et al., 2005).

\section{Sampling Details}

Ferrari et al. (2005) demonstrated the occurrence of three magmatic episodes in Veracruz area: (1) a middle Miocene (approx. 15-11 Ma) episode in the southern part; (2) a late Miocene to early Pliocene (approx. 7.5-3 Ma) pulse of mafic alkaline volcanism throughout the study region; (3) a late Pliocene to Quaternary transitional to calc-alkaline volcanism. According to these authors, whereas the first and third episodes may be considered as part of the subductionrelated TMVB, the second pulse of volcanism has a more complex origin.

Our sampling strategy was largely conditioned by Ferrari 


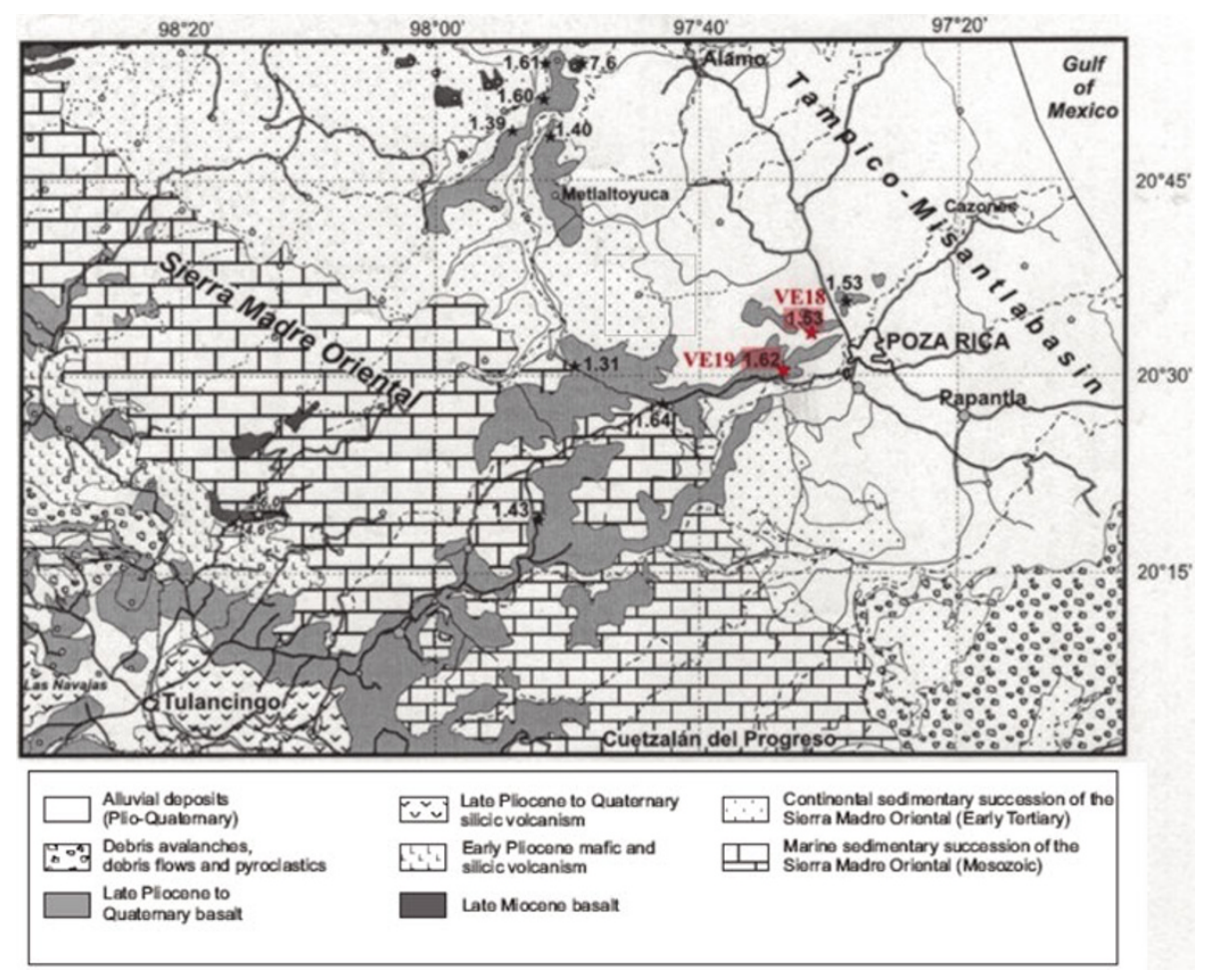

Fig. 4. Geological map of the Tulancingo-Poza Rica region showing the location of sites VE18 and VE19 (retrieved from Ferrari et al., 2005).

et al.'s (2005) recent study which gave 46 new unspiked $\mathrm{K}$ Ar ages for the EAP. We sampled only sites with available radiometric dating information (Figs. 2, 3 and 4; Table 1) that were easy to access and which yielded fresh, apparently unaltered outcrops. In total, 162 oriented standard paleomagnetic cores belonging to 19 individual lava flows were collected. The samples were distributed throughout each flow, both horizontally and vertically, in order to minimize effects of possible block tilting. Most samples were obtained at the very bottom of the flows in the hope of collecting samples with the finest grains (mostly 'small' pseudosingle domain structure) of material. Cores were sampled with a gasoline-powered portable drill and then oriented, in most cases, with both magnetic and sun compasses. There are no sections with visible consecutive lava flows and horizon markers and, thus, no possibility of establishing an unambiguous stratigraphic sequence. There are scattered lava flows without clear evidence of relative position. The studied sites generally present a single lava flow without any evidence of under- and overlying units.

The sampling was carried out along four areas (see Figs. 2-4; Table 1).

Sierra de Tantima and Alamo volcanic field (7.6-6.6 Ma). Sierra de Tantima is a 19-km-long, 5-km-wide and 1320-mhigh mountain with a marked NE alignment (Fig. 2). At its center, it consists of a 700-m-thick succession of mafic lava flows, with negligible dip, that cover early Tertiary sandstones and shales. The flows are typically $2-10 \mathrm{~m}$ thick, compositionally ranging from basanite to hawaiite. The Alamo field comprises at least 40 monogenetic volcanoes that surround the Sierra de Tantima (Fig. 2). Because of erosion, lava flows are rarely preserved, and a neck of massive lava is the only main evidence of the volcanic structure
(Ferrari et al., 2005).

Tlanchinol flows (7.3-5.7 Ma). On the west of the Alamo volcanic field (Fig. 2), several massive lava flows are exposed on the eastern slope of the Sierra Madre Oriental (SMO) between Tlanchinol and Huejutla. The volcanic succession is as thick as $250 \mathrm{~m}$ in places, and the lavas are aphyric to microporphyritic with olivine and pyroxene phenocrists (Ferrari et al., 2005).

Chiconquiaco-Palma Sola area (6.9-3.2 Ma). Cenozoic volcanism in the Chiconquiaco-Palma Sola region spans a longer time interval than the areas to the north (Fig. 3). It consists of four group of rocks: (1) middle to late Miocene intrusive bodies of gabbroic to dioritic composition, mainly exposed along the coast; (2) latest Miocene to early Pliocene alkaline basaltic plateau centered in the Chiconquiaco area; (3) latest Pliocene shoshonitic lava flows of the Alto Lucero; (4) Late Pleistocene to Holocene cinder cones with associated lava flows mostly located to the south of Chiconquiaco plateau.

Poza Rica lavas (1.6-1.3 Ma). Several massive mafic flows cover the eastern slope of the SMO west of Poza Rica (Fig. 4). Ferrari et al. (2005) indicate that these lavas flowed for over $90 \mathrm{~km}$ from the front of the SMO west of Huachinango to the coastal area, filling paleo-valleys and reaching a thickness of several hundreds of meters. Two other large lavas flows are exposed northwest of Poza Rica in the Metlatoyuca area. The lavas are porphyritic with olivine and clinopyroxene as phenocrysts.

\section{Magnetic Measurements and Data Analysis 3.1 Curie points and hysteresis loops}

In order to identify the magnetic carriers of the remanent magnetization and to obtain information about their pale- 
(a)
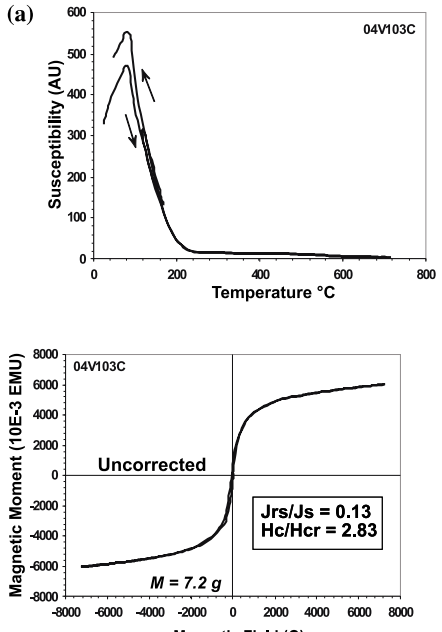

Magnetic Field (G)

(b)
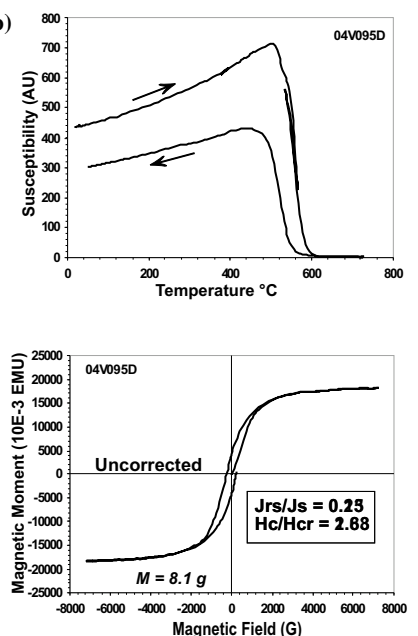
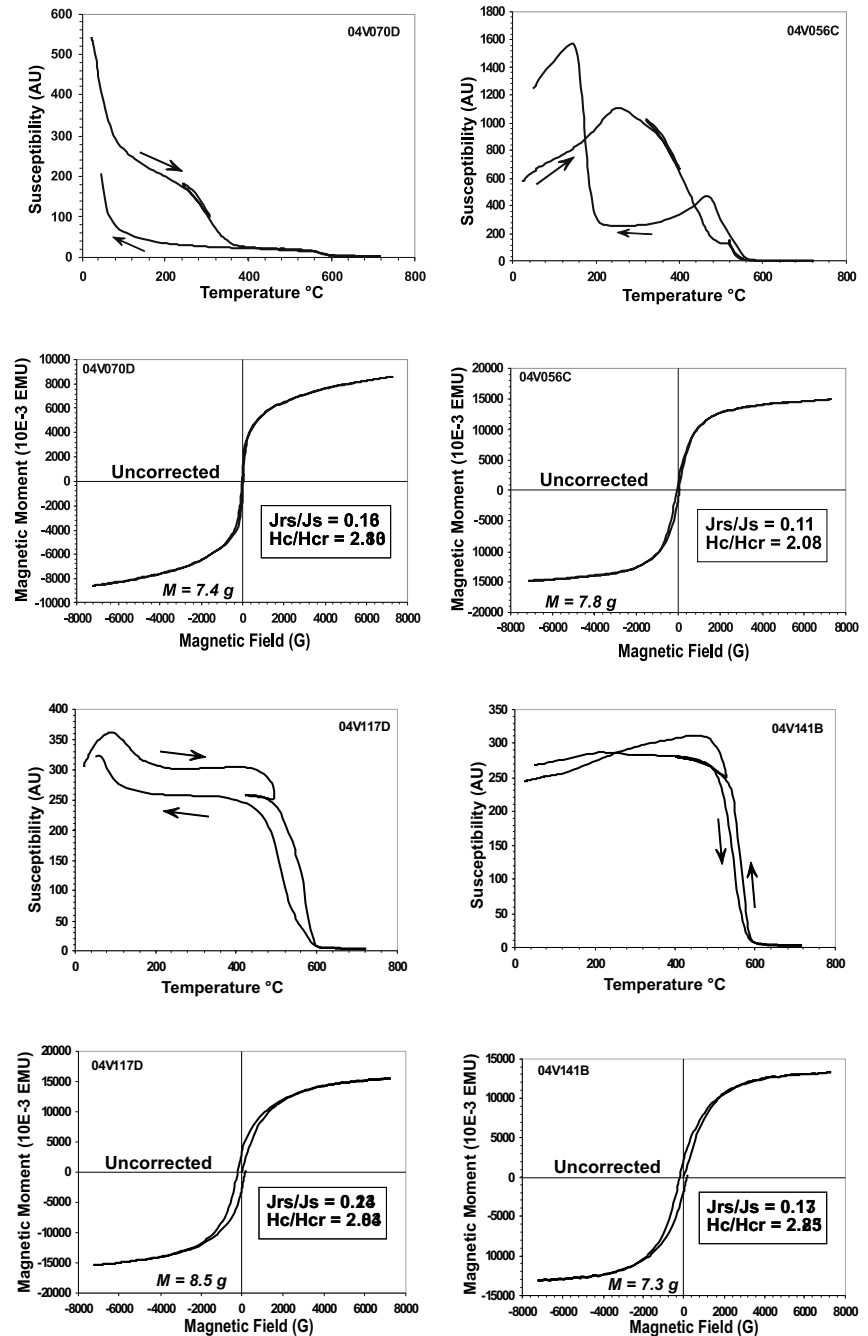

Fig. 5. Susceptibility versus temperature (in air) curves of representative samples (the arrows indicate the heating and cooling curves) and typical examples of hysteresis loops (uncorrected for paramagnetism) of small chip samples from the studied volcanic flows.

omagnetic stability, rock magnetic experiments were carried out. These experiments included: (1) measurements of continuous thermomagnetic curves (low-field susceptibility versus temperature) and (2) hysteresis experiments. Low-field susceptibility measurements (K-T curves) under air were carried out using Kappabridge Agico KLY-3S susceptibility systems equipped with a CS-3 furnace. One sample from each site was heated up to about $700^{\circ} \mathrm{C}$ at a heating rate of $20^{\circ} \mathrm{C} / \mathrm{min}$ and then cooled at the same rate. Curie temperature was determined by Prévot et al.'s (1983) method.

Representative thermomagnetic curves are presented in Fig. 5(a) and (b) (upper parts). In most cases (12 sites; Fig. 5(a)), the curves show the presence of a single magnetic phase with a Curie point compatible with relatively Ti-poor titanomagnetite (samples 04V095D and 04V141B). However, in some cases, the cooling and heating curves are not perfectly reversible (04V095D). Sample 04V117D (Fig. 5(a)) demonstrates some indications of the co-existence of both Ti-poor and Ti-rich titanomagnetites. The lowest Curie point ranges between 100 and $150^{\circ} \mathrm{C}$, while higher ones reach almost $565^{\circ} \mathrm{C}$, which is indicative of Ti-poor titanomagnetite. In few samples, the ap- parent presence of a single phase corresponding to the Tirich titanomagnetites (the Curie points range between 170 and $360^{\circ} \mathrm{C}$; samples 04V103C and 04V070D) are detected. Here again, the heating and cooling curves are not perfectly reversible (this is particularly true for sample 04V070D), probably because of heating under air and the relatively high heating/cooling rate $\left(20^{\circ} \mathrm{C} / \mathrm{min}\right)$ used during these experiments. An 'enigmatic' behavior was observed for sample 04V056C. The heating curve shows only a single phase, with a Curie temperature close to that of magnetite, while two phases appear to be present during the cooling, making it difficult to interpret the well-defined transformation at about $200^{\circ} \mathrm{C}$. No clear evidence of titanomaghemites or titanohematites was detected during the continuous K-T measurements.

Hysteresis measurements were performed at room temperature on one specimen from all of sampled sites using the translation inductometer of the Paleomagnetic Laboratory of Saint Maur in fields up to 0.7 Tesla. The saturation remanent magnetization $\left(\mathrm{J}_{\mathrm{rs}}\right)$, the saturation magnetization $\left(\mathrm{J}_{\mathrm{s}}\right)$ and the coercive force $\left(\mathrm{H}_{\mathrm{c}}\right)$ were calculated after correction for the paramagnetic contribution. The coercivity of remanence $\left(\mathrm{H}_{\mathrm{cr}}\right)$ was determined by applying a progressively 
Table 2. The hysteresis parameters for the EAP sites (The coercivity of remanence $\mathrm{H}_{\mathrm{cr}}$, the coercive force $\mathrm{H}_{\mathrm{c}}$, the saturation remanent magnetization $\mathrm{J}_{\mathrm{rs}}$ and the saturation magnetization $\mathrm{J}_{\mathrm{S}}$ ).

\begin{tabular}{cccccccc}
\hline Site & Sample & $\begin{array}{c}\mathrm{H}_{\mathrm{c}} \\
(\mathrm{mT})\end{array}$ & $\begin{array}{c}\mathrm{H}_{\mathrm{cr}} \\
(\mathrm{mT})\end{array}$ & $\begin{array}{c}\mathrm{J}_{\mathrm{s}} \\
\left(\mathrm{A} . \mathrm{m}^{2} / \mathrm{kg}\right) \\
\times 10^{-3}\end{array}$ & $\begin{array}{c}\mathrm{J}_{\mathrm{rs}} \\
\left(\mathrm{A} . \mathrm{m}^{2} / \mathrm{kg}\right) \\
\times 10^{-3}\end{array}$ & $\mathrm{H}_{\mathrm{cr}} / \mathrm{H}_{\mathrm{c}}$ & $\mathrm{J}_{\mathrm{rs}} / \mathrm{J}_{\mathrm{s}}$ \\
\hline VE01 & 04V009C & 13.07 & 21.83 & 51.7 & 22.77 & 1.67 & 0.44 \\
VE02 & 04V016C & 5.10 & 10.90 & 71.9 & 16.83 & 2.14 & 0.23 \\
VE03 & 04V019B & 11.42 & 18.42 & 293.1 & 90.5 & 1.60 & 0.31 \\
VE04 & 04V026C & 14.43 & 23.78 & 373 & 119.5 & 1.65 & 0.32 \\
VE05 & 04V038B & 10.04 & 20.83 & 1302 & 207.7 & 2.08 & 0.16 \\
VE06 & 04V041C & 10.73 & 31.5 & 725 & 153.3 & 2.93 & 0.21 \\
VE07 & 04V050C & 8.31 & 12.77 & 960 & 214.6 & 1.53 & 0.22 \\
VE08 & 04V056C & 7.05 & 14.63 & 1675 & 190.0 & 2.08 & 0.11 \\
VE09 & 04C070D & 3.58 & 7.52 & 877 & 140.4 & 2.10 & 0.16 \\
VE10 & 04V079C & 24.59 & 46.4 & 2185 & 608.0 & 1.89 & 0.29 \\
VE11 & 04V086D & 10.46 & 18.76 & 709 & 147.7 & 1.79 & 0.21 \\
VE12 & 04V095D & 24.26 & 40.8 & 2062 & 525.0 & 1.68 & 0.25 \\
VE13 & 04V103D & 4.60 & 13.00 & 653 & 84.0 & 2.83 & 0.13 \\
VE14 & 04V105C & 18.82 & 36.9 & 632 & 168.2 & 1.96 & 0.27 \\
VE15 & 04V117D & 18.79 & 38.4 & 1500 & 360.0 & 2.04 & 0.24 \\
VE16 & 04V127C & 3.72 & 8.97 & 531 & 98.1 & 2.41 & 0.18 \\
VE17 & 04V135D & 14.60 & 49.1 & 568 & 73.2 & 3.36 & 0.13 \\
VE18 & 04V141B & 19.39 & 43.7 & 1599 & 277.7 & 2.25 & 0.17 \\
VE19 & 04V147B & 6.58 & 16.66 & 548 & 136.3 & 2.5 & 0.25 \\
\hline & & & & & & &
\end{tabular}

increasing backfield following saturation. Typical hysteresis plots are given in Fig. 5(a) and (b) and Table 2. Judging from the ratios of hysteresis parameters (Table 2), all obtained data fall in the pseudo-single domain (PSD) grain size region (Day et al., 1977). This may also indicate a mixture of multidomain (MD) grains and a significant amount of single-domain (SD) grains (Dunlop and Özdemir, 1997; Dunlop, 2002).

\subsection{Remanence measurements}

The remanent magnetizations of seven to nine samples from each lava flow (Table 3 ) were measured with both JR5 and JR-6 (AGICO Ltd.) spinner magnetometers (nominal sensitivity: approx. $10^{-9} \mathrm{~A} \mathrm{~m}^{2}$ ). Both alternating field (AF) demagnetization using a laboratory made AF-demagnetizer (Le Goff, 1985) and stepwise thermal demagnetization (using a Saint Maur furnace) were carried out. A number of additional experiments were carried out at the paleomagnetic laboratory of the National University of Mexico (UNAM).

A characteristic remanent magnetization was successfully isolated for most of samples (Fig. 6). In some cases (samples 04V042, 04V148), small secondary components, probably due to viscous magnetic overprint, were present and easily removed by applying a $20-\mathrm{mT}$ alternating peak field or $200^{\circ} \mathrm{C}$. Most of the remanent magnetization was usually removed at temperatures between 500 and $540^{\circ} \mathrm{C}$, which point once again to Ti-poor titanomagnetites being the carriers responsible for magnetization. Few samples showed unblocking temperatures between 250 and $300^{\circ} \mathrm{C}$ (sample $04 \mathrm{~V} 148 \mathrm{~A}$ ), indicating the presence of Tirich titanomagnetite in accordance with susceptibility vs. temperature experiments. As attested in Fig. 6 (samples 04V121C and 04V116B), some remanence survives above the Curie point of magnetite, which may be attributed to (titano)hematite (this is consistent with the high coercivity
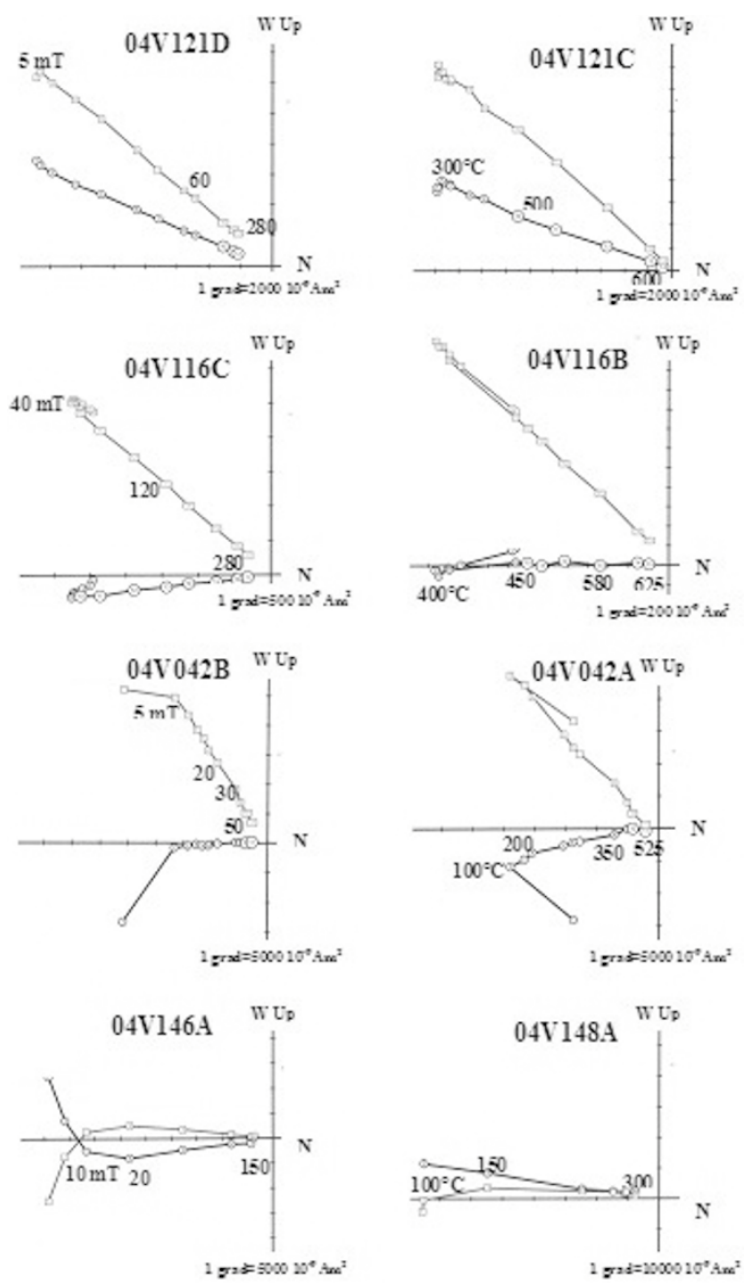

Fig. 6. Orthogonal vector plots of stepwise thermal or alternating field demagnetization of representative samples (stratigraphic coordinates). The numbers refer either to the temperatures (in ${ }^{\circ} \mathrm{C}$ ) or to peak alternating fields (in $\mathrm{mT}$ ).

components found during the $\mathrm{AF}$ treatments performed on sister samples) not seen on K-T curves or, alternatively, to the formation of (some) new magnetic minerals from the original titanomagnetites during the heating in air. In any case, it is very clear that both low- and high-coercivity components carry essentially the same paleodirections.

The characteristic magnetization direction was determined by the least squares method (Kirschvink, 1980), with five to nine points being taken into account for the principal component analysis for this determination. Directions were averaged by unit, and the statistical parameters were calculated assuming a Fisherian distribution.

\section{Main Results and Discussion}

The characteristic paleodirections are successfully isolated for all units. Eleven sites yielded reverse magnetic polarity, six are normally magnetized and two lava flows (VE14 and VE09) provided apparently intermediate paleodirections (Table 3; Fig. 7(a)). These last sites were disregarded for the calculation of the mean directions. The mean directions from normal units are: $D=354.9^{\circ}, I=32.4^{\circ}$, $n=6, k=34, \alpha_{95}=11.6^{\circ}$, while the reversed polarity lavas yielded $D=2.1^{\circ}, I=31.1^{\circ}, n=11, k=27, \alpha_{95}=8.9^{\circ}$. The 

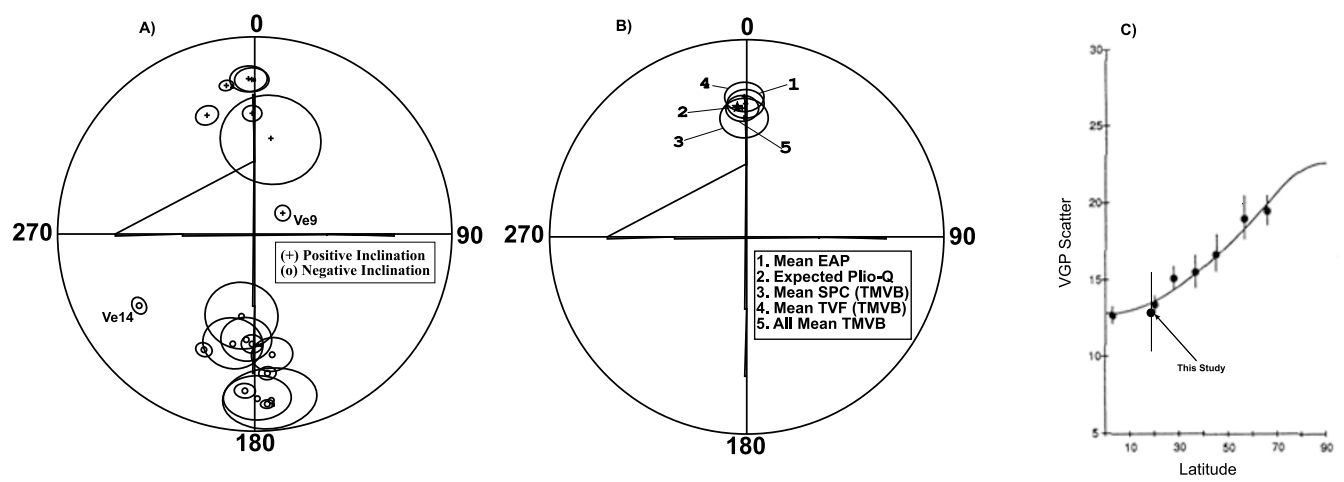

Fig. 7. (a) Equal area projections of the flow-mean characteristic paleodirections for the EAP volcanics. (b) The mean EAP paleodirections shown together with the recently available mean directions from TMVB. (c) Estimate of total angular dispersion (PSV) for the paleodirectional data from EAP plotted in the diagram of paleosecular variation of lavas (PSVL) for the last $5 \mathrm{Ma}$. (PSV model diagram modified from McFadden et al., 1991).
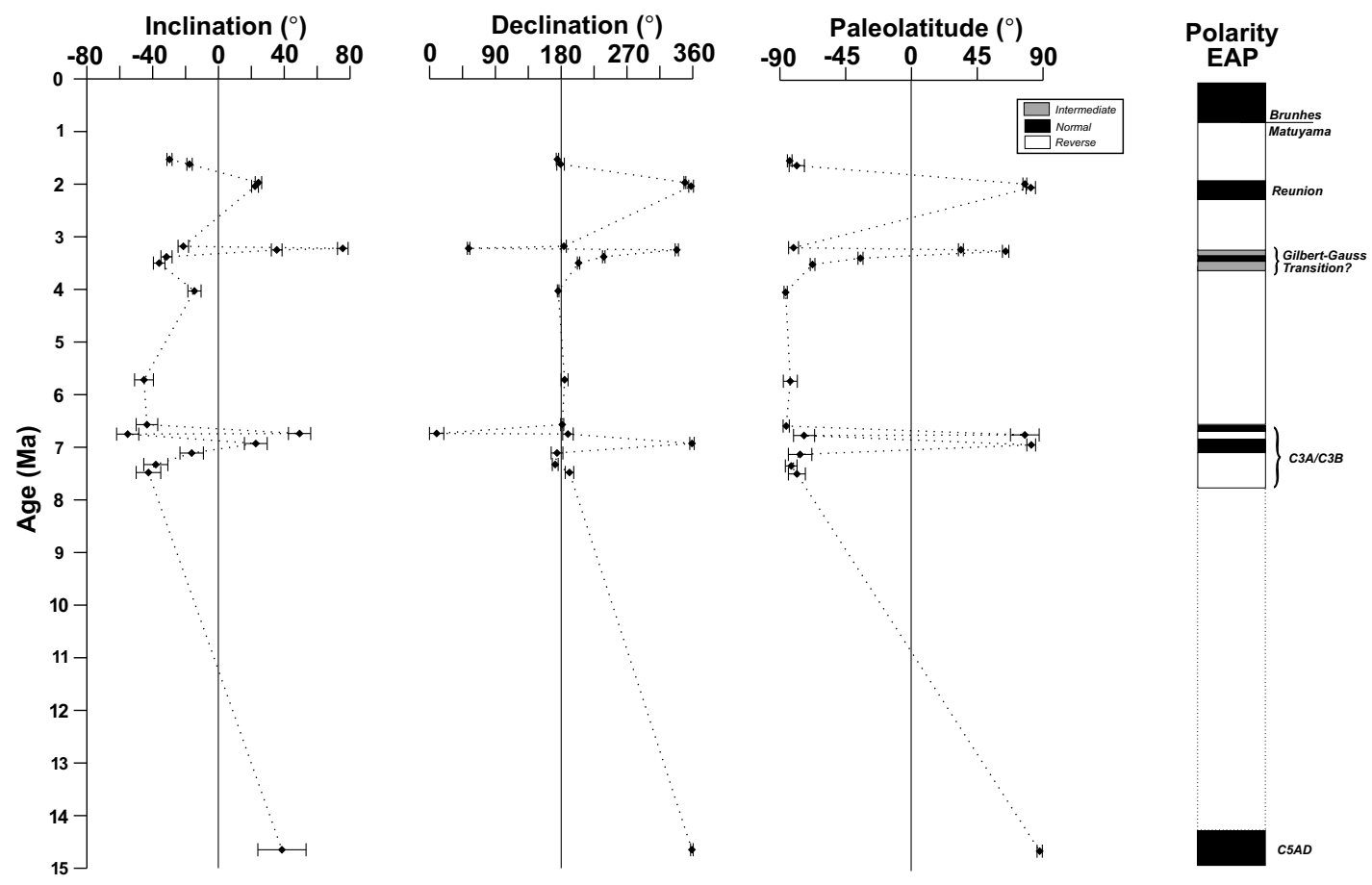

Fig. 8. Flow-mean magnetic declination, inclination and paleolatitude of virtual geomagnetic poles against age.

combination of normal and reverse polarity lavas gave $D=359.8^{\circ}, I=32.9^{\circ}, n=17, k=30, \alpha_{95}=6.7^{\circ}$. This direction is practically indistinguishable from the expected MioPliocene paleodirection, as derived from reference poles for the North American polar wander curve (Besse and Courtillot, 2002). It is also in agreement with recently reported directions from the Trans-Mexican Volcanic Belts (Petronille et al., 2005; Rodriguez-Ceja et al., 2006). All of these results suggest that no major tectonic deformation occurred in studied area from the middle Miocene to the Present. Both EAP and TMVB yield statistically indistinguishable paleodirections.

The classic formula $S_{F}^{2}=S_{T}^{2}-S_{W}^{2} / n$ was used to estimate paleosecular variation in this study where, here, $S_{T}$ is the total angular dispersion $S_{T}=\left[(1 / N-1) \sum_{i=1}^{N} \delta i^{2}\right]^{1 / 2}$ (Cox, 1969; McFadden et al., 1991), $N$ is the number of sites used in the calculation, $\delta_{i}$ is the angular distance of the $i$ th virtual geomagnetic pole from the axial dipole, $S_{W}$ is the within site dispersion and $n$ is the average number of samples per site. Using the new data obtained in this study, we obtained $S_{F}=12.7$ with $S_{U}=16.5$ and $S_{L}=10.3$ (upper and lower limits, respectively). The virtual geomagnetic pole scatter is thus consistent (Fig. 7(c)) with the value predicted by the latitude-dependent variation model of McFadden et al. $(1988,1991)$ for the last 5 Myr. A similar conclusion was recently reached by Conte et al. (2006) based on their study of lava flows associated to the Michoacan Guanajuato Volcanic Field.

The paleomagnetic declination, inclination and paleolatitude of the VGP obtained in this study are shown in Fig. 8 against their stratigraphic position.

- The oldest site analyzed (VE08) yielded normal polarity magnetizations. This flow possibly emplaced during the chron C5AD (Gradstein et al., 2004).

- Five sites dated between 7.45 and 6.57 Ma gave 
Table 3. Flow-mean paleodirections of cleaned remanence for EAP sites. $N$, number of treated samples; $n$, number of specimens used for calculation; Inc, Inclination; Dec, Declination; $k$ and $\alpha_{95}$; precision parameter and radius of $95 \%$ confidence cone of Fisher statistics, respectively; Plat/Plong, latitude/longitude of VGP position; Pol, magnetic polarity.

\begin{tabular}{ccccccccc}
\hline Site & $n / N$ & Inc. $\left(^{\circ}\right)$ & Dec. $\left(^{\circ}\right)$ & $\alpha_{95}\left(^{\circ}\right)$ & $k$ & Plat. $\left({ }^{\circ}\right)$ & Plong. $\left(^{\circ}\right)$ & Pol. \\
\hline VE18 & $8 / 8$ & -29.8 & 174.8 & 3.1 & 287 & -83.3 & 210.5 & $\mathrm{R}$ \\
VE19 & $7 / 8$ & -17.6 & 179.1 & 11.3 & 87 & -78.5 & 281.5 & $\mathrm{R}$ \\
VE10 & $8 / 8$ & 24.3 & 349.2 & 2.5 & 621 & 77.5 & 141.1 & $\mathrm{~N}$ \\
VE13 & $7 / 7$ & 22.2 & 357.7 & 6.4 & 86 & 81.6 & 98.9 & $\mathrm{~N}$ \\
VE12 & $8 / 8$ & -21.4 & 183.6 & 3.6 & 295 & -80.7 & 240.7 & $\mathrm{R}$ \\
VE09 & $8 / 8$ & 75.6 & 53.3 & 3.2 & 281 & 33.8 & 289.5 & $\mathrm{I}$ \\
VE11 & $8 / 9$ & 35.4 & 338.1 & 4.3 & 159 & 64.4 & 176.5 & $\mathrm{~N}$ \\
VE14 & $8 / 8$ & -31.6 & 238.2 & 3.2 & 284 & -34.9 & 165.8 & $\mathrm{I}$ \\
VE16 & $7 / 8$ & -36.1 & 203.7 & 3.1 & 392 & -67.7 & 168.7 & $\mathrm{R}$ \\
VE17 & $7 / 8$ & -14.6 & 175.8 & 2.2 & 893 & -86.1 & 359.9 & $\mathrm{R}$ \\
VE05 & $9 / 9$ & -45.3 & 184.6 & 9.7 & 65 & -82.9 & 116.9 & $\mathrm{R}$ \\
VE03 & $4 / 7$ & -43.5 & 181.4 & 4.1 & 288 & -85.7 & 99.4 & $\mathrm{R}$ \\
VE02 & $7 / 7$ & 49.3 & 9.6 & 19.6 & 12 & 77.5 & 304.3 & $\mathrm{~N}$ \\
VE04 & $8 / 8$ & -55.2 & 189.2 & 14.4 & 28 & -73.5 & 109.4 & $\mathrm{R}$ \\
VE07 & $7 / 8$ & 22.7 & 358.9 & 5.9 & 141 & 81.9 & 91.0 & $\mathrm{~N}$ \\
VE01 & $4 / 9$ & -16.3 & 174.3 & 15.6 & 26 & -76.2 & 286.3 & $\mathrm{R}$ \\
VE06 & $7 / 7$ & -38.1 & 171.8 & 7.7 & 78 & -82.3 & 355.9 & $\mathrm{R}$ \\
VE15 & $6 / 8$ & -42.6 & 191.3 & 11.4 & 48 & -78.4 & 87.7 & 234.9 \\
VE08 & $7 / 8$ & 38.6 & 358.8 & 3.6 & 481 & & $\mathrm{~N}$ \\
\hline
\end{tabular}

mixed magnetic polarities. These lavas were probably erupted during chrons $\mathrm{C} 3 \mathrm{~A}$ and $\mathrm{C} 3 \mathrm{~B}$.

- Two sites dated 3.38 \pm 0.06 and 3.22 $\pm 0.06 \mathrm{Ma}$, respectively, provided intermediate polarity magnetization, while the lava flow dated as $3.25 \pm 0.06$ Ma showed a normal polarity. This instability can be associated to the Gilbert-Gauss transition or to the Mammoth excursion. However, judging from this unusual behavior, age determination problems cannot be completely discarded.

- An interesting feature of the paleomagnetic record obtained from EAP volcanics is that two independent flows (VE13 and VE10), dated as 2.04 \pm 0.04 and $1.97 \pm 0.04 \mathrm{Ma}$, respectively, both yield normal paleodirections. These lavas were apparently emplaced during the worldwide observed Réunion event. Chamalaun and MacDougal (1966) yielded the first evidence of this excursion, reporting the possible occurrence of a short event around 2 Myr ago based upon paleomagnetic and $\mathrm{K}-\mathrm{Ar}$ age investigation of volcanic rocks from Réunion island. Later, Sueishi et al. (1979) found two short normal polarity intervals in the Matuyama epoch in two deep-sea cores taken from the western equatorial Pacific: one is dated at about $1.07 \mathrm{Ma}$, but the second is dated at about 1.94 Ma. Since this important discovery, many localities worldwide have confirmed the Réunion event (MacDougal et al., 1992; Baksi et al., 1993; Carlut et al., 1999; Kidane et al., 1999; Baksi and Hoffman, 2000; Roger et al., 2000; Hornh et al., 2002; Lanphere et al., 2002). However, no firm conclusions have as yet been reached about the duration and nature of the Réunion event. Some authors (e.g. Kidane et al., 1999) even speculate on the existence of two short successive periods with paleointensity minimums at 2.02 and 2.14 Ma, respectively.

- Our two youngest lava flows (VE18 and VE19), dated as $1.53 \pm 0.03$ and $1.62 \pm 0.05 \mathrm{Ma}$, respectively, yielded reverse polarity magnetization, as expected for the units belonging to the Matuyama chron.

Acknowledgments. The present work was carried out thanks to ECOS (France)-ANUIES-CONACYT (Mexico) agreement on bilateral cooperation. This study was supported by UNAM-DGAPA (grant no. IN102007). AG is grateful to the financial support provided by CONACYT grant no 42661 .

\section{References}

Baksi, A. K., A. K. Hoffman, and C. Mcwilliams, Testing the accuracy of the geomagnetic polarity time-scale (GPTS) at 2-5 Ma, utilizing ${ }^{40} \mathrm{Ar} /{ }^{39} \mathrm{Ar}$ incremental heating data on whole-rock basalts, Earth Planet. Sci. Lett., 118, 135-144, 1993.

Baksi, A. K. and A. K. Hoffman, On the Age and Morphology of the Réunion Event, Geophys. Res. Lett., 27, 2997-3000, 2000.

Besse, J. and V. Courtillot, Apparent and true polar wander and the geometry of the geomagnetic field over the last $200 \mathrm{Myr}$, J. Geophys. Res., 107(B11), 1029/2000JB000050, 2002.

Bohnel, H. and J. F. W. Negendank, Preliminary results of palaeomagnetic measurements of Tertiary and Quaternary igneous rocks from the eastern part of the Trans-Mexican Volcanic Belt, Geofis. Int., 20(3), 235248, 1981.

Bohnel, H., J. Urrutia-Fucugauchi, and E. Herrero-Bervera, Paleomagnetic data from central Mexico and their use for paleosecular variation studies, Phys. Earth Planet. Inter., 64, 224-236, 1990.

Carlut, J., J. P. Valet, X. Quidelleur, V. Curtillot, T. Kidane, Y. Gallet, and P. Y. Gillot, Paleointensity across the Réunion Event in Ethiopia, Earth Planet. Sci. Lett., 170, 17-34, 1999.

Chamalaun, F. H. and I. McDougall, Dating geomagnetic polarity epochs in Réunion, Nature, 210, 1212, 1966.

Coe, R., S. Singer, B. S. Pringle, and X. Zhao, Matuyama-Brunhes reversal and Kamikatsura event on Maui: paleomagnetic directions, ${ }^{40} \mathrm{Ar} /{ }^{39} \mathrm{Ar}$ ages and implications, Earth Planet. Sci. Lett., 222, 667-684, 2004.

Conte, G., J. Urrutia-Fucugauchi, A. Goguitchaichvili, and J. Morales, Low-latitude paleosecular variation and the time-averaged field during the late Pliocene and Quaternary-Paleomagnetic study of the Michoacan-Guanajuato volcanic field, Central Mexico, Earth Planets Space, 58, 1359-1371, 2006.

Cox, A., Lengths of geomagnetic polarity intervals, J. Geophys. Res., 73, 3247-3260, 1968

Cox, A., Confidence limits for the precision parameter k, Geophys. J. R. Astr. Soc., 17, 545-549, 1969. 
Day, R., M. Fuller, and V. A. Schmidt, Hysteresis properties of titanomagnetites: Grain-size and compositional dependence, Phys. Earth Planet. Inter., 13, 260-267, 1977.

Dunlop, D. J., Theory and application of the Day plot (Mrs/Ms versus $\mathrm{H}_{\mathrm{cr}} / \mathrm{H}_{\mathrm{c}}$ ), Theoretical curves and tests using titanomagnetite data, J. Geophys. Res., 107, doi:10.1029/2001JB000486, 2002.

Dunlop, D. and Ö. Özdemir, Rock-Magnetism, Fundamentals and Frontiers, Cambridge University Press, 573 pp, 1997.

Ferrari, L., T. Tagami, M. Eguchi, M. T. Orozco-Esquivel, C. M. Petrone, J. Jacobo-Albarrán, and M. López-Martínez, Geology, geochronology and tectonic setting of late Cenozoic volcanism along the Southwestern Gulf of Mexico: The eastern alkaline province revised, J. Volcanol. Geotherm. Res., 146, 284-306, 2005.

Gómez-Tuena, A., A. LaGatta, C. Langmuir, S. Goldstein, F. OrtegaGutiérrez, and G. Carrasco-Núñez, Temporal Control of Subduction Magmatism in the Eastern Trans-Mexican Volcanic Belt: Mantle Sources, Slab Contributions and Crustal Contamination, Geochem. Geophys. Geosyst., 4(8), 8912, doi:10.1029/2003GC000524, 2003.

Gonzalez, S., G. Sherwood, H. Bohnel, and E. Schnepp, Paleosecular variation in Central Mexico over last 30,000 years: the record from lavas, Geophys. J. Int., 130, 201-219, 1997.

Gradstein, F., J. Ogg, and A. G. Smith, Geologic Time Scale 2004, Cambridge University Press, Cambridge 2004.

Herrero-Bervera, E., J. Urrutia-Fucugauchi, A. Martin del Pozzo, H. Bohnel, and J. Guerrero, Normal amplitude Brunhes paleosecular variation at low-latitudes: A paleomagnetic record from the Trans-Mexican Volcanic Belt, Geophys. Res. Lett., 13, 1442-1445, 1986.

Horng, C. S., M. Y. Lee, H. Palike, K. Y. Wei, W. T. Liang, Y. Iizuka, and $\mathrm{M}$. Torii, Astronomically calibrated ages for geomagnetic reversals within the Matuyama chron, Earth Planets Space, 54, 679-690, 2002.

Kidane, T., J. Carlut, V. Courtiullot, Y. Gallet, X. Quidelleur, P. Gillot, and T. Haile, Paleomagnetic and geochronological identification of the Réunion subchron in Ethiopian Afar, J. Geophys. Res., 104, 1040510419, 1999.

Kirschvink, J. L., The least-square line and plane and analysis of palaeomagnetic data, Geophys. J. R. Astron. Soc., 62, 699-718, 1980.

Lanphere, M. A., D. E. Champion, R. L. Christiansen, and T. Obradovich, Revised ages for tuffs of the Yellowstone, Geol. Soc. Am. Bull., 114, 559-568, 2002.

Lawrence, K. P., C. G. Constable, and C. L. Johnson, Paleosecular variation and the average geomagnetic field at $\pm 20^{\circ}$ latitude, Geochem. Geophys. Geosyst., 7, Q07007, 2006.

Le Goff, M., Description d'un appareil à désaimanter par champs alternatifs; élimination de l'aimantation rémanente anhystérétique parasite, Can. J. Earth Sci., 22, 1740-1747, 1985.

McDougall, I., F. H. Brown, T. E. Cerling, and J. W. Hillehouse, A reappraisal of The geomagnetic polarity time scale to 4 Ma using data from the Turkana basin, East Africa, Geophys. Res. Lett., 19, 2349-2352, 1992.

McFadden, P., T. Merrill, and W. McElhinny, Dipole/quadrupole family modeling of paleosecular variation, J. Geophys. Res., 93, 11583-11588, 1988.

McFadden, P. L., R. Merrill, M. W. McEllhinny, and S. Lee, Reversals of the Earth's magnetic field and temporal variations of the dynamo families, J. Geophys. Res., 96, 3923-3933, 1991.
Mejia, V., H. Bohnel, M. A. Ortega-Rivera, J. Lee, and J. ArandaGomez, Paleosecular variation and time-averaged field recorded in Late Pliocene-Holocene lava flows from Mexico, Geochem. Geophys. Geosyst., 6, doi:10.1029/2004GC000871, 2005.

Petronille, M., A. Goguitchaichvili, B. Henry, L. Alva-Valdivia, J. RosasElguera, M. Rodríguez Ceja, and M. Calvo-Rathert, Paleomagnetism of Ar-Ar dated lava flows from the Ceboruco-San Pedro volcanic field (western Mexico): Evidence for the Matuyama-Brunhes transition precursor and a fully reversed geomagnetic event in the Brunhes chron, $J$. Geophys. Res., 110, b08101, doi:10.1029/2004jb003321, 2005.

Prévot, M., R. S. Mainkinen, S. Grommé, and A. Lecaille, High paleointensity of the geomagnetic field from thermomagnetic studies on rift valley pillow basalts from the middle Atlantic ridge, J. Geophys. Res., 88, 2316-2326, 1983.

Robin, C., Présence simultanée de magmatismes de significations tectoniques opposées dans l'Est du Mexique, Bull. Soc. Geol. Fr., 18, 1637-1645, 1976.

Robin, C., Relations volcanologie-magmatologie-géodynamique: application au passage entre volcanismes alcalin et andésitique dans le sud Mexicain (Axe Trans-Mexicain et Province Alcaline Orientale), Ph.D. Thesis, Annales Scientifiques de l'Université de Clermont-Ferrand II France, 503 p, 1982.

Rodriguez-Ceja, M., A. Goguitchaichvili, M. Calvo-Rathert, J. MoralesContreras, L. Alva-Valdivia, J. Rosas Elguera, and H. D. Granados, Paleomagnetism of the Pleistocene Tequila Volcanic Field (Western Mexico), Earth Planets Space, 58, 1349-1358, 2006.

Roger, S., C. Coulon, N. Thouveny, G. Feraud, A. Van Velzen, S. Fauquette, J. J. Cocheme, M. Prevot, and K. L. Verosub, ${ }^{40} \mathrm{Ar} /{ }^{39} \mathrm{Ar}$ dating of a tephra layer in the Pliocene Senèze maar lacustrine sequence (French Massif Central): constraint on the age of the Réunion-Matuyama transition and implications on paleoenvironmental archives, Earth Planet. Sci. Lett., 183, 431-440, 2000.

Ruiz-Martinez., V. C., M. L. Osete, and R. Vegas, Palaeomagnetism of Late Miocene to Quaternary volcanics from the eastern segment of the Trans-Mexican Volcanic Belt, Tectonophysics, 318, 217-233, 2000.

Singer, B. S., M. K. Relle, K. A. Hoffman, A. Battle, C. Laj, H. Guillou, and J. C. Carracedo, Ar/Ar ages from transitionally magnetized lavas on La Palma, Canary Island, and the geomagnetic instability timescale, $J$. Geophys. Res., 107(B11), doi:10.1029/2001JB001613, 2002.

Steele, K. W., Paleomagnetic constraints on the volcanic history of Iztaccihuatl, Geof. Int., 24, 159-167, 1985.

Sueishi, T., T. Sato, N. Kawai, and K. Kobayashi, Short geomagnetic episodes in the Matuyama epoch, Phys. Earth Planet. Inter., 19, 1-11, 1979.

Urrutia-Fucugauchi, J., Constraints on Brunhes low-latitude paleosecular variation-Iztaccíhuatl stratovolcano, basin of Mexico, Geof. Int., 34, 253-262, 1994.

Urrutia-Fucugauchi, J., Comments on a new method to determine paleosecular variation, Phys. Earth Planet. Inter., 102, 295-300, 1997.

A. Goguitchaichvili (e-mail: avto@geofisica.unam.mx), M. Petronille, B. Henry, L. Alva Valdivia, J. Morales, and J. Urrutia-Fucugauchi 